\title{
Editorial
}

\section{Research Insights and Challenges for Facilitating Critical Thinking}

Critical thinking is currently considered to be a vital skill, since the individual is supposed to be able to critically evaluate situations, give arguments for his/her opinions and evaluate the arguments of other people, identify other people's manipulative behaviour, pose problem-based questions, and develop his/her mental capabilities. Critical thinking is significant, as it enables a person to make better quality personal decisions, increases the chance of success in achieving goals and solving problems, and enlarges autonomy and effectiveness of coping with different circumstances. Researchers emphasise that critical thinking is the precondition of maintaining social democracy. It helps the individual and the society in confronting social problems and solving them.

In the field of education we wonder to what extent it is possible to teach and learn critical thinking - in a direct or indirect way. Which means can the teacher use in order to facilitate critical thinking in his/her students? To what extent can problem-based instruction contribute to the development of critical thinking? Which competences does the teacher need in order to be able to facilitate critical thinking in his/her students, and what kind of teacher education will ensure at least basic knowledge needed for the enforcement of the concepts of critical thinking? Critical thinking is strongly connected to the teacher's reflection of (his/her own) practice, which is a prerequisite for quality teaching and teacher's professional development.

In the focus of this issue, there are six contributions by authors from Croatia, Serbia, Slovenia, and Finland. Four refer to the development of critical thinking in school contexts (either from the teachers' or the students' points of view) and two refer to the process of teacher education. Within the school context, we can facilitate critical thinking through teaching compulsory and optional subjects, extracurricular activities, and through other forms of school work (e.g. culture, science, technical and sports days; field trips; etc.).

It is critical that the teacher familiarises students with different skills of critical thinking and introduces suitable strategies into instruction wisely and intentionally. In their article, What is Needed to Develop Critical Thinking in Schools, Lidija Radulović and Milan Stančić discuss how education for critical thinking is conceptualised. Their paper presents an analysis of the predominant approach to education for critical thinking through implementation of special programmes and methods, and an attempt to establish different approaches to education for 
critical thinking. The overview and analysis of understanding education for developing critical thinking as the implementation of special programmes reveal that it is perceived as a decontextualised activity, reduced to practicing individual intellectual skills. The authors introduce a new conceptual view of the development of critical thinking based on critical pedagogy and open curriculum theory, which emphasises the reconstruction of the status, role and power of students and teachers and the process of curriculum development.

Project work, especially if it is systematically and intentionally carried out through the phases of initiative, drafting, planning, implementation and evaluation, can contribute significantly to the development of critical thinking skills in students. To what extent the teacher implements project work and supports student critical activity in respective phases is also dependent on the teacher's conceptions of instruction, knowledge and his/her attitudes. In the paper Project Activities and Encouraging Critical Thinking: Exploring Teachers' Attitudes, authors Petra Pejić Papak, Lidija Vujičić and Željka Ivković present results of a study carried out on a sample of 220 elementary school teachers from Croatia. The objectives of the research were to determine the regularity of implementing project activities at the class level and at the level of the entire school, and to examine possible differences between teachers who estimated regular implementation of project activities in their schools and those who estimated irregular implementation of project activities in the application of contemporary work strategies, as well as in the attitudes on the contemporary paradigm of childhood and educational processes. The research results showed that teachers who reported regular implementation of project activities at the class level as well as at the school level, more frequently applied contemporary work strategies and techniques of critical thinking than their colleagues did.

Constructivist instruction that emphasises student's cognitive activity can significantly support the development of students' critical thinking. In the contribution Critical Thinking as a Dimension of Constructivist Learning: Some of the Characteristics of Students of Lower Secondary Education in Croatia, Tomislav Topolovčan and Milan Matijević present results of a study carried out on a sample 703 students of the final grade of lower secondary education in Croatia. The aim of this study was to examine the characteristics of the frequency of constructivist learning and its dimensions, including critical thinking, the differences in them with regard to certain demographic characteristics, and correlations with the frequency of use of certain new media in teaching students. The results show that students assessed a significantly higher incidence of critical thinking in relation to the dimensions of constructivist learning. In respect to every latent dimension of constructivist learning, (all) students with 
a higher grade point average are inclined towards a higher assessment of the frequency of the personal relevance of learning, critical thinking and collaborative learning.

For teachers to be ready and qualified to carry out instruction and other activities that could contribute to the development of critical thinking in students, it is necessary that they have also experienced it themselves in the process of initial as well as further teacher education. The abilities of in-depth reflection and critical consideration are some of the most important factors of teacher's professional development (Valenčič Zuljan et al., 2011). There are two articles that deal with the facilitation of teacher reflection. Barbara Šteh and Marjeta Šarić are the authors of the paper Critical Reflection in the Professional Development of Teachers: Challenges and Possibilities. They present an overview of different perspectives on critical reflection in the context of teachers' professional development and then underscore some empirical research findings on the problems that teachers and teacher educators face when they put reflection into practice, especially at the deeper and more complex levels of reflection. The authors emphasise that obstacles can occur at the level of individual teachers' personal traits and at the level of the context in which reflection is done. Employing the analysis of the obstacles, the authors draw up some guidelines on how to support teachers in their attempts at making critical reflection part of their teaching practice.

Branko Bognar and Irena Krumes are the authors of the contribution Encouraging Reflection and Critical Friendship in Pre-service Teacher Education. To explore how to encourage students' reflection, they carried out a two-year research project impelling student teachers to become mutual critical friends. Inquiry was conducted on a sample of 27 students, within the course Correlated-integrated systems in Croatian language teaching. For critical friendship communication and other project activities they utilised Moodle (an online learning management system). On the basis of the analysed data, which were gathered at the end of each action research cycle, the authors prove that the students felt comfortable in the role of critical friends and that critical friends' reflections were particularly important to them. In classifying the levels of reflection, the authors refer to the established Van Mannen model (1977), which made a distinction between technical, practical, and critical levels of reflectivity. The research showed that the technical mode of reflective thinking prevails in the students' correspondence. The practical or contextual level could rarely be observed while critical reflection was often completely absent.

The final paper of the focus part of the issue is by Esa Virkkula and SädePirkko Nissilä with the title Towards Professionalism in Music: Self-assessed 
Learning Strategies of Conservatory Music Students. This study concerns music education and vocational music students' self-observed learning strategies. The research was carried out on a sample of 62 students. The aim of the research was formed into three research questions: (1) What kind of learning strategies were observed in the music students' descriptions of learning? (2) How consciously did the music students utilise learning strategies in the music workshops? (3) What were the music students' most essential learning experiences in the workshop work and performances according to their self-assessment? A significant observation comes from cross-professional collaboration. The professional musicians who participated in the project represented the same profession, but not the same instruments as the students. In that sense, the workshops offered cross-professional collaboration. This study emphasises the outcomes of changing relationships between educational experts and practitioners.

Varia covers two contributions: the authors Maša Đurišić and Mila Bunijevac write about Parental Involvement as an Important Factor for Successful Education while Mojca Kovač Šebart and Roman Kuhar discuss The Pluralisation of Family Life: Implications for Preschool Education. In the Reviews section, the book by Jonathan Bergmann and Aaron Sams, Flipped Learning: Gateway to Student Engagement, is reviewed by Romina Plešec Gasparič, and the book by David Mitchell, Diversities in Education: Effective Ways to Reach All Learners, is reviewed by Nika Šušterič.

\section{Jana Kalin and Milena Valenčič Zuljan}

\section{References}

Van Manen, M. (1977). Linking ways of knowing with ways of being practical. Curriculum inquiry, 6(3), 205-228.

Valenčič Zuljan, M., Vogrinc, J., Cotič, M., Fošnarič, S., \& Peklaj, C. (2011). Sistemski vidiki izobraževanja pedagoških delavcev [Systemic Aspects of Pedagogical Worker Education]. Ljubljana: Pedagoški inštitut. 